\title{
A Legitimacy-based Approach to EU Criminal Law: : Maybe We Are Getting There, After All
}

\section{Nuotio, Kimmo}

2020-03-01

Nuotio , K 2020 , ' A Legitimacy-based Approach to EU Criminal Law: Maybe We Are

Getting There, After All ' , New Journal of European Criminal Law , vol. 11 , no. 1 , pp. 20-39

. https://doi.org/10.1177/2032284420903386

http://hdl.handle.net/10138/311923

https://doi.org/10.1177/2032284420903386

cc_by

publishedVersion

Downloaded from Helda, University of Helsinki institutional repository.

This is an electronic reprint of the original article.

This reprint may differ from the original in pagination and typographic detail.

Please cite the original version. 


\title{
A legitimacy-based approach to EU criminal law: Maybe we are getting there, after all
}

New Journal of European Criminal Law 2020, Vol. II (I) 20-39 (C) The Author(s) 2020 (c) (1)

Article reuse guidelines: sagepub.com/journals-permissions DOI: 10.1 1 77//2032284420903386 njecl.sagepub.com

@SAGE

\author{
Kimmo Nuotio (1) \\ University of Helsinki, Finland
}

\begin{abstract}
European Union (EU) law is known for its strong emphasis on effectivity and more generally for its instrumental character. This is not foreign even to European criminal law, a feature which creates some tension between the EU criminal law and criminal law in the national setting. EU Framework Decisions and Directives often require the Member States to criminalize certain forms of conduct with sanctions that are 'Effective, Dissuasive and Proportionate'. In this article, I try to show that it would be timely to look at EU criminal law from an alternative point of view, as a more mature law. I call this a legitimacy-based approach. Such a reading would ease some of these tensions. It would also be helpful in developing a criminal policy for the EU, a policy which would be realistic and pragmatic. And it would be easier to look at EU criminal law from the point of view of justice. In order to get there, we need to see where the (current) narrow deterrence argument gets is wrong or one-sided. Some social theory is needed in order to make the point.
\end{abstract}

\section{Keywords}

Deterrence, general prevention, justice, legitimacy, sense of justice, relative comparability

\section{A thought experiment}

The birth of European Union (EU) criminal law has not been an easy one. Since the drafting of the Maastricht Treaty, the Member States of the EU have seen the necessity of increased collaboration in that field, but they have been cautious in giving away legislative powers to decide on crime and punishment. The story is well known and does not need to be retold here.

Nordic scholars in particular - including myself - have criticized EU criminal law on the grounds that it represents a far more instrumental approach than that which is characteristic of the criminal policy of the Nordic countries, and that it would risk leading to increased repression if

\section{Corresponding author:}

Kimmo Nuotio, Faculty of Law, University of Helsinki, Yliopistonkatu 3, 000 I 4 Helsinki, Finland.

E-mail: kimmo.nuotio@helsinki.fi 
implemented in full. ${ }^{1}$ Raimo Lahti, for instance, has analysed the tension between EU and Nordic criminal policy. ${ }^{2}$

The point I wish to make in this article is rather simple. Maybe we could, even as a kind of thought experiment, look at EU criminal law not only from the perspective of its shortcomings and deficits, but from the point of view of its achievements and its potential. European criminal law is a legal construct, and the way we construct or reconstruct it accordingly matters for what it is.

Instead of a merely critical analysis, this article presents an alternative view; an alternative vision. Its point is that we may have been using too simplistic a model of how law works and becomes effective in a society. We might have to add a bit of idealism to our realism. Maybe we have not yet realized that as criminal policy matures, it must also change substantially. We may need a bit of social theory to see this point. Broadening our perspective on European criminal law enables us to see more of its nuances.

The perspective that I wish to introduce is that of legitimacy, which I take to include some symbolic aspects as well. ${ }^{3}$ If it is our law, and not just something imposed on us, then such a perspective makes sense. Legitimacy draws on a variety of sources: on democracy, human rights, rule of law, decent and rational criminal policy and so on. This links to broader and deeper issues concerning how we think about the role of the Area of Freedom, Security and Justice ('AFSJ') as one of the constitutive, defining elements of the EU as a polity. ${ }^{4}$ In this article, we will focus mainly on just one aspect of the AFSJ, namely the narrow emphasis on effectiveness and deterrence - a core feature of European criminal law.

\section{Hard deterrence}

The belief in (hard) deterrence has been a meeting ground for different efforts and points of view at the EU level. The use of criminal law has been a tempting option for the EU Commission, since it represents something more than just administrative sanctioning. And for the EU Commission, the main worry has constantly been the lack of effectiveness of EU law. The effet utile principle has been characterized as a constitutional master principle of EU law. This, in turn, has led to an instrumental view of criminalization: criminal law as a means to other ends. ${ }^{5}$ I would like to invite us to think about criminal law as an institution, in non-instrumental terms. Paradoxically, law might work better when grasped this way.

The sanctioning force of criminal law is nothing new, since in some sense the coercive force may even be regarded as a defining factor of legality. How we understand and read law is a matter of choice. To my mind, we have too easily been denying a 'legal' reading of European criminal law. I want to make a few remarks on this matter.

1. T Elholm, 'Does EU Criminal Cooperation Necessarily Mean Increased Repression?' (2009) 17 European Journal of Crime, Criminal Law \& Criminal Justice 191, 219.

2. Raimo Lahti, 'Towards a Principled European Criminal Policy: Some Lessons from the Nordic Countries' in J BanachGutierrez and C Harding (eds), EU Criminal Law and Policy: Values, Principles and Methods (Routledge, London 2017) 56-69. See also K Nuotio, 'The Rationale of the Nordic Penal Policy Compared with the European Approach' in K Nuotio (ed), Festschrift in Honour of Raimo Lahti (Publications of the Faculty of Law of the University of Helsinki, Forum Iuris 2007) 157.

3. Whether to criminalize business cartels or not is a debate in which the symbolical effects of criminal law play a role as well. See the discussion in Patrik S Günsberg, 'Exploring the Case for Criminalisation of Business Cartels in Europe' in Banach-Gutierrez and Harding (eds) (n 2) 212, 224.

4. See, eg, Massimo Fichera, The Foundations of the EU as a Polity (Edward Elgar, Cheltenham 2018).

5. K Tuori, 'Ultima Ratio as a Constitutional Principle' (2013) 3 Oñati Socio-Legal Series 6, 18. 
Much of EU criminal law reasoning builds on the view that law works as a deterrent. For a rational potential offender, the risk of detection and punishment is an extra burden which the potential offender will choose to avoid. Simply by taking a different look at how criminal law in fact works, we could open up a fresh perspective on many of the most central issues in EU criminal law. We do not have to abandon the idea of hard deterrence completely. But we should enrich it by stressing especially the positive dimension of 'general prevention' inherent in the deterrence paradigm. By reading EU criminal law in this new way, we could alleviate the tension observed by Raimo Lahti and many others. Seeing alternatives to hard deterrence is not that difficult. Proportionality, for instance, is one obvious alternative. A tempting one, and a one that may serve as a bridge. The 'act-proportionality' perspective, namely the idea that a sanction must be proportionate to the seriousness of the sanctioned act, which is discussed in more detail below, picks up the point of view of values.

I wish to discuss the aim of punishment from two intertwined angles, namely the level of EU criminal law and the level of domestic criminal law. EU criminal law is, of course, a rather special case since it does not concern criminal law directly, but rather organizes the way criminal law is used at the national level. It inter alia sets the minimum requirements in some cases in this respect.

In the following section, we will first look at the understanding of what punishments are expected to deliver, that is, what requirements arise from the level of EU law. We see a trend towards a more mature criminal policy view at this level. The highly interesting thing is how this European level interacts with the level of the national legal orders. Bridges between these orders should be built to bring about an approximation of values, not merely of laws. We have a few remarks on what potential we have to build further on that, once we open up our perspective a bit.

\section{'Effective, dissuasive and proportionate'}

Even before the EU enjoyed formal competence in matters criminal, EU law repeatedly included the poorly defined notion that penalties applied for infringements of EU law on the national level must be 'effective, dissuasive and proportionate'. The term 'penalty' includes administrative and other sanctions: the Member States are required to enforce Union law but are broadly free to choose the means by which they do this. In its case law, the Court of Justice of the European Union ('CJEU') has interpreted the phrase 'effective, dissuasive and proportionate'.

This formulation is also used more narrowly in the EU criminal law context strictu sensu, since the same standard formulation has been included in the Framework Decisions and later Directives requiring Member States to criminalize certain activities in their domestic legislation. Often EU Framework Decisions and Directives also require that the penalty scales provided for in the national legal orders need to allow for extradition or surrender of the suspected person. In most jurisdictions, this requires that the penalty scale provides for a sentence of imprisonment.

Article 5 of the Directive on the counterfeiting of the Euro, ${ }^{6}$ to give just one example, states that for certain offences, the offences shall be punishable by a maximum sanction which provides for imprisonment. For some offences, that maximum must be at least eight years' imprisonment.

6. Directive 2014/62/EU of the European Parliament and of the Council of 15 May 2014 on the protection of the euro and other currencies against counterfeiting by criminal law, and replacing Council Framework Decision 2000/383/JHA [2014] OJ L151/1. 
The secret formula itself has, however, never really been formally defined. It originates in the case law of the CJEU. Already in the famous Greek Maize case, ${ }^{7}$ we find the formula being used:

... whilst the choice of penalties remains within their discretion, they must ensure in particular that infringements of Community law are penalized under conditions, both procedural and substantive, which are analogous to those applicable to infringements of national law of a similar nature and importance and which, in any event, make the penalty effective, proportionate and dissuasive.

In the case law of the CJEU, the contents of this formula have been further elaborated and specified. We may only refer here to a few cases as examples. The Texdata Software Case C-418/1 $1^{8}$ approached the issue from both sides; the penalties must be punitive enough, but not too punitive. It becomes also clear that the Court only gives guidance on how to interpret the formula, but the final interpretation and application is for the national authority applying the law. In the Case LCL Le Crédit Lyonnais, ${ }^{9}$ the Court went on to determine the contents of the formula in the general area of sanctioning the EU law infringements on the national level and developed a test for assessing the dissuasiveness of the measure.

In any event, we find a much more reduced use of the formula of 'dissuasive, effective and proportionate sanctions' in the context of EU criminal law strictu sensu. It seems that this arises from the fact that the harmonization model adopted for cooperation in legal matters is generally minimum harmonization only, meaning that the Member States have discretion when implementing the Framework Decisions and Directives. Today, the obligations have been set in a rather detailed manner which in turn decreases the independent role of the formula.

It deserves to be mentioned that for the Court criminal penalties seem to be generally more dissuasive than other penalties due to the particular nature of criminal sanctioning. This can be seen in the famous ruling annulling the Council Framework Decision on the protection of the environment on the grounds that it had been adopted using the wrong legal basis, because the provisions could have instead been included in a Directive made under Community environmental competence. ${ }^{10}$ In this case, it was difficult for the Council to contest the argument of the Commission since the Framework Decision was precisely meant to introduce obligations for the Member States to ensure that they provide protection of the environment through criminal law in their national legislation.

All three components of the formula are somewhat vague. Effectiveness should be taken to mean that the regulation will have an impact of the activities regulated. But it does not give any clear model about how to estimate this. Effectiveness means thus suitability of the legal and policy instruments to serve the goals set by the legislature.

Proportionality has, as is generally known, two possible interpretations. There is act-proportionality which requires that the punishment should be proportionate to the gravity of the offence. The second interpretation is means-end-proportionality. This second interpretation of proportionality would obviously be close to the effectiveness test. In criminal law, act-proportionality is particularly significant, since it reveals the penal value of the act in question. It is rather obvious that sentences that are both effective and proportionate may help with the internalization of those

7. Case C-68/88 Commission v Greece [1989] ECR I-2965 para 24.

8. Case C-418/11 Texdata Software GmbH [2013] ECR General Court Reports.

9. Case C-565/12 LCL Le Crédit Lyonnais SA v Fesih Kalhan [2014] ECR General Court Reports.

10. Case C-176/03 Commission v Council [2005] ECR I-7879. 
values and also give reasons for potential perpetrators not to engage in the forbidden conduct. Proportionality and effectiveness are thus internally linked. If we look at this discussion through the lenses of a legitimacy perspective, the effectiveness in some sense always gets realized through systemic legitimacy. The criminal sanctions should be appropriate: they should not be too lenient, but nor should they be too harsh.

And, finally, we would have to define what we mean by dissuasive penalties. Michael Faure, who has studied this, takes this to be the 'Gary Becker and law and economics' part: dissuasiveness would mean that the prospect of these penalties would neutralize the incentive to commit the offence. ${ }^{11}$ Effectiveness is also related to dissuasiveness, since obviously in order for the regulation to be effective, it must be somewhat dissuasive as seen from the point of view of the actors within the field. We might say that the two concepts take different perspectives: dissuasiveness adopts the perspective of an actor within the field, whereas effectiveness adopts a systemic point of view. In fact, proportionality also has a link with dissuasiveness: the risk of a proportionate criminal sanction provides the potential perpetrator with reasons not to commit the offence, and thus has a dissuasive effect. We see even here that there is more than one way to theorize dissuasiveness: we could look at it in a more narrow deterrence perspective, or we could adopt a broader perspective which allows for our motivations to act be influenced by issues of values. We may simply share the values informing our laws, which makes it easier for us to comply.

After having briefly dealt with the formula 'effective, dissuasive and proportionate', we could reflect on what is excluded by this definition. This question is not quite as easy as it may seem. I would wish to explore whether should take a fresh look at how we understand general deterrence in this setting.

We have two ways of looking at this. The negative deterrence point of view highlights the fact that the threat of punishment operates as a reason not to commit the offence. This line of thought can be followed all the way to P.J.A. Feuerbach, who developed his famous theory that psychological coercion ${ }^{12}$ was necessary in order to safeguard freedom in a society given the temptation to violate the rights of others. The threat of punishment was needed to counteract this temptation. Thus, the fear of punishment was to be kept alive by enforcing the commands of law when breached by individuals.

There is a long line of theorizing about this mechanism of fear of sanctions motivating people not to breach legal obligations. According to law and economics theories, human behaviour can be looked at as rational. Human beings (as well as legal persons) are selfish and would choose to act wrongfully, unless a threat of punishment had been introduced to counterbalance the short-term benefits that could be gained by breaching legal obligations.

Gary Becker (above) introduced microeconomic thinking in this field by claiming that rational actors need to be steered by sanctioning their actions accordingly. General deterrence requires that both the risk of being caught and the severity of criminal sanction will be kept high enough since the general deterrent effect is being determined as the product of the two values. If the (perceived) risk of being caught is low, even very high punishments would not do the job, whereas if the

11. M Faure, 'Effective, Proportional and Dissuasive Penalties in the Implementation of the Environmental Crime and Ship-source Pollution Directives: Questions and Challenges' (2010) 19 European Energy and Environmental Law Review 256. See also the fundamental GS Becker, 'Crime and Punishment: An Economic Approach' (1968) 76 Journal of Political Economy 169.

12. PJA Feuerbach, Lehrbuch des gemeinen in Deutschland gültigen peinlichen Rechts (Heyer, Giessen 1832) para 14. 
(perceived) risk of being caught is very high, rational actors would be persuaded not to offend, even if the punishments were low.

We could now make a first observation. The formula 'effective, dissuasive and proportionate' must cover both aspects. We could thus say that criminal punishments not only have to be heavy enough, but also that must be applied and enforced in case of breaches. Without adequate surveillance and punishment of offenders, not only effectiveness, but also dissuasiveness will suffer. For the EU, this part of the effective implementation is much more difficult to handle. The expectation is that the domestic legal order operates effectively and is thus able to ensure some minimum effectiveness of the investigation and prosecution of those crimes. From a deterrence point of view, we should again observe that an easy way to increase general deterrence would be to increase the risk of detection and prosecution. As previously stated, effectiveness and dissuasiveness are thus internally linked.

Even this rather brief survey shows that EU criminal law does not see criminal law as operating using a different logic than other types of law that seek to steer human behaviour. The fact that the same formula is being used for non-criminal as criminal sanctions indicates that criminal law is being seen in a similar light.

This is of course a discussion which we have had also in the domestic setting: how does criminal law strictu sensu differ from administrative law (or administrative criminal law) in this sense? This distinction is far from clear, if we think for instance of the distinction between criminal law strictu sensu and regulatory criminal law in England, or between Ordnungswidrigkeitenrecht and criminal law in German law. ${ }^{13}$ Criminal law and criminal conviction seem intrinsically to carry an aspect of moral blame or stigma, which is weaker or absent in the case of administrative sanctions. According to German law, legal persons can only be charged for administrative, not criminal, infractions. ${ }^{14}$ Ulrich Sieber has observed that the rise of Mega-Ordnungswidrigkeiten, such as fines for cartels, has challenged the existing distinction, especially due to the lower-level procedural safeguards provided for offences in the administrative category. ${ }^{15}$ The more interesting point is this: we can observe that the more we stress bare sanctioning in how we set the sanction for breach, the more instrumentally actors themselves respond.

In EU criminal law, this discussion concerning what renders criminal law different emerged especially in the context of the dispute over the correct legal basis of some Framework Decisions during the first years of the Amsterdam Treaty.

Advocate General (AG) Mazak's opinion delivered on 28 June 2007 is of particular significance in this regard. The opinion was issued in the case concerning the Framework Decision on ShipSource Pollution. Mazak discussed at length the ways in which criminal law stands out as a particular field of law. It uses 'the most severe and most dissuasive tool of social control punishments' and it 'delineates the outer limits of acceptable behavior' and, by doing this, 'protects the values held dearest by the community at large'. ${ }^{16}$

Criminal penalties also 'reflect particular social disapproval and are in that respect of a qualitatively different nature as compared with other punishments such as administrative sanctions'.

13. R Williams, 'Criminal Law in England and Wales. Just Another Form of Regulatory Tool?' in M Dyson and B Vogel (eds), The Limits of Criminal Law: Anglo-German Concepts and Principles (Intersentia, Cambridge 2018) 207.

14. W Wohlers, 'Criminal Law as a Regulatory Tool' in Dyson and Vogel (eds) (n 13) 235.

15. Ulrich Sieber, 'Administrative Sanction in German Criminal Law' in Dyson and Vogel (eds) (n 13) 301.

16. AG Mazak, Opinion in Case C-440-/05 Commission v Council [2007] ECR I-9097 para 67. 
He continues that it can safely be said that 'criminal law is characterised by its dissuasive or deterrent nature'. It should, however, be borne in mind that 'deterrence is not the only identifiable purpose of criminal law'. ${ }^{17}$

He also makes the observation that there is 'no uniform concept of the notion of criminal law and the Member States may have very different ideas when it comes to identifying in closer detail the purposes which it should serve and the effects it may have'. ${ }^{18}$

There are several things that are significant in this Opinion. As understood by AG Mazak, one way to reconcile different views would be to say that the dominant view on the EU law level (an instrumental view of criminal law as a tool of social control) holds for the domestic level as well, but that this only covers one of the purposes of criminal law. Thus, domestic law may add other layers, as it certainly does.

We do not have to engage in detail with this discussion, which dates back to the pre-Lisbon era. The place of criminal law in the context of the EU legal (and constitutional law) framework has to some extent been settled by the Lisbon Treaty. The existence of the emergency brake, for instance, reveals the sensitive character of criminal legislation on the EU level.

There is something very important and interesting in AG Mazak's remarks. EU law looks at national criminal law through a narrower lens than that used by domestic law. But while this is so, this narrower, instrumentalist view of criminal law is not exclusively an EU creature: it also forms a part of national criminal law.

AG Mazak is very clear that the EU law looks at criminal law from the narrow point of view of effectiveness only. He formulates this aptly:

although its [criminal law's] deterrent effect means that there is certainly a correlation between criminal law and effectiveness, effectiveness does not entirely encapsulate the essence of criminal law. $[\ldots]$ the policy considerations behind the use of criminal penalties in a given community go well beyond the mere question of effective enforcement. ${ }^{19}$

What is then the hidden part which the subordination under the principle of effectiveness precludes us from seeing? AG Mazak highlights as one of the special characteristics the expressive function of the criminal law: criminal law reflects social disapproval. Criminal law communicates blame, and the communication of blame may even be part of the mechanism by which law operates and becomes effective in society. This is what we will take a look at next.

\section{Criminal law as moral education}

The idea that criminal law becomes effective indirectly rather than directly is not new. Whereas von Liszt and the sociological school had emphasized the special preventive function of criminal law, the Uppsala school and the Scandinavian realists emphasized general prevention. General prevention was, however, not understood as being based on the fear of punishment, as it had been presented by P.J.A. Feuerbach (above), for instance. Criminal law was rather understood to perform its function by supporting and creating morals in the society.

17. ibid.

18. ibid paras 69,70 .

19. ibid para 118 . 
The idea of moral education as the aim of systems of punishment had been previously presented by Ludwig von Bar in Germany. ${ }^{20}$ In the case of the Swedish scholars, Per Olof Ekelöf was particularly interested in how criminal law performs its function in moral education. ${ }^{21}$ Johannes Andenaes later extensively studied this idea. ${ }^{22}$ It has since become a generally accepted view that the communication of blame is a central feature of criminal law when looked at in its societal context. Criminal law expresses values and even conceptions of justice.

These days, the idea that criminal law works indirectly in this way is broadly accepted: criminal law and the practices of prosecution and conviction support the protection of the core values of the society by communicating blame and blameworthiness. This in turn requires that the public views criminal law, as well as its procedural law, to be a legitimate way of the forbidden conduct. Only through this 'experienced legitimacy' may the law succeed in making people transcend the narrow perspective of their own self-interest.

Accordingly, today it is common for research to criticize the narrow and instrumental view of general deterrence. We could refer to Tom R. Tyler's lifetime of work on why people obey the law $^{23}$ as well as to Christoph Engel's findings on how we learn the law. ${ }^{24}$ Even in the field of regulatory studies we find views which stress very different approaches to regulating and preventing crime. ${ }^{25}$ There exists an entire literature on the shortcomings of a narrow law and economics rationality model, drawing on advances in empirical psychology. ${ }^{26}$ The symbolic dimension of legislation continues to be an important aspect of debates concerning bio law, for instance. ${ }^{27}$

In modern theories of punishment, the various viewpoints are often being combined. Both special prevention and general prevention matter. Besides general deterrence, the so-called 'positive general prevention' also plays a role. Even restorative justice may be significant for some practices.

It is not a surprise that EU criminal law does not share or reproduce all of the fine-grained details of Member States' domestic criminal law and the theories of punishment which have inspired them. As we have seen, the history of European integration may have affected the formation of the EU criminal approach. Originally, from the point of view of European integration, national criminal law and criminal justice were only tools for sanctioning breaches of Community (as it then was) law.

Today this is no longer the case. Europe is regarded as a judicial area, as an AFSJ. Judicial cooperation in criminal matters is an integral part of that. What, then, makes the discussion of the

20. Ludwig von Bar, A History of Continental Criminal Law (Little, Brown and Company, Boston 1916) 497.

21. Per Olof Ekelöf, Straffet, skadeståndet och vitet. En studie över de rättsliga sanktionernas verkningssätt (A.-b. Lundequistska bokhandeln, Uppsala 1942) 12.

22. Johannes Andenaes, Punishment and Deterrence (University of Michigan Press, Michigan 1974).

23. Tom R Tyler, Why People Obey the Law (Princeton University Press, New Jersey 2006); Tom R Tyler and Yuen J Huo, Trust in the Law: Encouraging Public Cooperation with the Police and Courts (Russell Sage Foundation, New York 2002).

24. Christoph Engel, 'Learning the Law' Preprints of the Max Planck Institute for Research on Collective Goods, Bonn, 2004/5<https://papers.ssrn.com/sol3/papers.cfm?abstract_id=539982> accessed 24 January 2020.

25. See, for instance, Christopher Hodges, Law and Corporate Behaviour: Integrating Theories of Regulation, Enforcement, Compliance and Ethics (Hart Publishing, Oxford 2015).

26. Cf., for instance, D Kahneman, Thinking, Fast and Slow (Allen Lane, London 2011)

27. Rob Schwitters, 'How Law Matters: Sociological Reflections on the Symbolic Dimension of Legislation' in B van Klink, B van Beers and L Poort (eds), Symbolic Legislation Theory and Developments in Biolaw (Springer, Cham 2016) 55-69. 
aims of punishment at the EU law level so difficult? Clearly, the EU does not aim to harmonize the deeper ideological premises of criminal law, since quite obviously the domestic legal traditions may vary substantially.

We should, however, see that communication of core values through criminal law and justice is not something that is completely irrelevant for EU criminal law. Having 'effective, dissuasive and proportionate' criminal sanctions for serious cross-border crimes is very important for European citizens. EU criminal law has moved beyond the stage where we can say that it only has an instrumental value. Taking a European perspective, something new emerges. What emerges is, however, not a copy of a national system, but something different.

One way of approaching this dilemma or tension would be to look at it from the point of view of the legitimacy of EU criminal law. I understand that this was also the approach of the group of academics which produced the Manifesto document. ${ }^{28}$ To my mind, however, the drafters of that document were still closely tied with existing developments and lacked the imagination to paint a larger picture. One of the aims of the group was certainly to assess whether and how EU criminal policy as practised was 'rational', rationality being assessed against principles elaborated by the drafters. The drafters were conscious that what they proposed was a sort of Enlightenment critique of the law as then practised.

Still one has to consider that, originally, before the Lisbon era, criminal law cooperation could be regarded as belonging to international law. This was the argument made by the Member States in order to limit the powers of the Commission and the (then) Community law actors in disputes concerning how Community law related to (then) Council-based cooperation within justice and home affairs.

\section{Criminal policy for a mature polity}

The legitimacy of EU criminal law does not, however, only grow from below. Especially in the post-Lisbon framework, a variety of institutional reforms are reflecting new understandings which deserve attention. The increased role of the European Parliament, to give just one example, strengthens the democratic legitimacy of the measures adopted. The active development of European human rights law should of course also be mentioned, not to mention about the Charter of Fundamental Rights ('the Charter'). The Charter clearly applies to the exercise of powers in the field of criminal justice. The accession of the EU to the European Convention of Human Rights, required by the Lisbon Treaty, would also further increase the legitimacy of EU criminal law. The current struggles concerning the rule of law and independence of the judiciary in some Member States, in turn, are real challenges especially since the measures based on mutual recognition, such as the European Arrest Warrant, ${ }^{29}$ tie all the jurisdictions together. As a result, a rule of law problem in one of the Member States has an impact on all of the others.

If we accept the view that the legitimacy of EU criminal law has indeed increased as a result of these concurrent developments, we might gain a new point of view to look at how EU criminal law is supposed to become effective.

28. European Criminal Policy Initiative, 'The Manifesto on European Criminal Policy' (2011) 1 European Criminal Law Review 86.

29. Council Framework Decision 2002/584/JHA of 13 June 2002 on the European arrest warrant and the surrender procedures between Member States [2002] OJ L190/2. 
The point is simply that if we emphasize the so-called 'positive general prevention' or 'moral education' point of view, we draw more on the legitimacy of criminal law and less on the fear of punishment. ${ }^{30}$ This will most obviously affect the design of European criminal policy. We would no longer measure the performance of individuals and companies solely by resorting to a rational actor model. We would see that the addressee of criminal laws could in fact be taken to be the lawabiding citizen.

This shift of perspective would be radical since it would change the entire register in which we conduct this debate. We would no longer consider minimum rules concerning criminal definitions and punishments only under the angle of their limited effectiveness, but we would rather see that the EU approach to criminal law fits criminal law ultimate objectives, namely that law-abiding citizens understand the moral communication of values. This difference would be clearest in the case of actors such as companies which certainly strive to make profit and seek economic interest. The questions of how companies act and whether a company understands blame, for instance, become the real test.

I would, still, make the caveat: the aim is not to completely do away with general deterrence and the narrow economic rationality it represents, but rather to highlight the significance and even primacy of positive general prevention. In Habermasian terms, we would read criminal law as an institution. To my mind, even European criminal law itself can already be read in those terms.

What I suggest is that we would look at criminal justice in terms of symbolic and moral communication instead of as a technical tool for steering rational actors. In such a view, actproportionality becomes essential: we shift from means-end-proportionality to act-proportionality. We should of course not exaggerate our ability to build on the moral communication point of view, but we should not downplay it either. Symbolic use of criminal law could even be a problem, if this would mean a lower threshold for criminalizing behaviour. The European Parliament has referred to this risk in its Resolution on criminal policy: ' . . it is not sufficient to refer to abstract notions or to symbolic effects, but that the necessity of new substantive criminal law provisions must be demonstrated by the necessary factual evidence.... 31

We should in any case look at this option more closely, since disregarding it entails a high cost: we will be doomed to an 'administrative sanction' type of approach, with no real access to the domain of criminal law. We would thus be doomed to a managerial position, without being able to address the issues by their true name. This would be a contradiction which could, for reasons of principle, never be solved.

Objections could be raised, and need to be considered. One could object to the entire idea of introducing a legitimacy perspective on the EU criminal law and see it as still being very thin in terms of common values. This criticism deserves attention. One should, however, also be able to update views on the proper nature of EU criminal law. It is rather obvious that many of the surrounding parameters have changed and would at least modestly support our claim.

The other objection would state that the subject matters of EU criminal law do not allow for such a reading. When addressing, through criminal policy, issues such as terrorism and organized

30. This would mean a similar turn to that which the Enlightenment critique produced for criminal procedure: the accused is now a subject of the proceedings, not merely an object. See F Wolfgang, 'Einheit und Vielfalt des Strafrechts in Europa' in Nuotio (ed) (n 2) 7, 16-17.

31. European Parliament Resolution of 22 May 2012 on an EU approach to criminal law (2010/2310(INI)) pt Q.3. 
cross-border crime, talk about the citizen's perspective and moral communication does not make sense.

This is a difficult question, I admit. Do we really think that a high degree of legitimacy of the criminal law would make a difference in the case of highly organized and highly motivated crime which challenges the very presumptions of our legal orders?

My answer would be that human rights, as well as decent crime policies, are the best protection against such threats. There is no way we could promote security through criminal justice without committing ourselves to the legitimacy perspective. Thus, I do not see how we could build an 'enemy criminal law' which would enjoy a high legitimacy. An inclusive legal perspective is simply part of the European heritage, since the Enlightenment, and it is only logical that we emphasize the role of legitimacy of criminal justice. This includes importantly also criminal procedure. This is where human rights law comes in.

A third criticism would be that by adopting this perspective, we risk removing all of the careful limitations on EU competence in this field. This criticism too must be met. We will later look at the risks involved in a symbolic use of law. I would say that we should not do away with existing limitations, but nor should we let them restrict out minds in interpreting what we have.

An emphasis on moral communication through criminal law does not mean reintroducing punishments of shaming. This is also already clear due to the critical tradition of Enlightenment, and such punishments would be prohibited by human rights law.

If I am right, we would have to reconsider the way we look at crime at the EU criminal law level. We should introduce a more nuanced and multifaceted approach, one which could be termed sociological. Not only would this mean that we would trust less law-and-economics-type calculations of the relevant levels of punishments. Following this value-oriented reading, we would look at EU-level laws as stating certain values. We would have to look at the role of human beings even in the case of legal persons (eg looking at companies' employees). This shift in perspective would lead us to conceptualize pretty much everything anew. This would, however, follow rather naturally from the already-existing body of values and guarantees. In terms of crime prevention, we would look at questions such as whistle-blowing more closely, we would try to cultivate responsible business cultures and we would adjust our regulations accordingly. ${ }^{32}$

What if we refused to take this path, and instead continued with the current narrow perspective? How would the world look like then? My answer would be that the tensions between EU and national criminal law would then continue to exist, and may even grow bigger. This is not merely a tension between different kinds of legal materials; it is a clash of two rationales. Such a tension is very difficult to resolve.

Fortunately, the EU has begun to reflect on issues of criminal policy (or criminal law policy). A Communication was published by the Commission in $2011 .^{33}$ This document includes some seeds indicating that a new conception might be able to grow. According to the Communication, criminal law 'reflects the basic values, customs and choices of any given society'. The EU thus respects the

32. See European Commission, 'Proposal for a Directive of the European Parliament and of the Council on the protection of persons reporting on breaches of Union law' COM (2018) 218 final, 23 April 2018.

33. European Commission, 'Towards an EU Criminal Policy: Ensuring the effective implementation of EU policies through criminal law' (Communication from the Commission to the European Parliament, the Council, the European Economic and Social Committee and the Committee of the Regions) COM (2011) 573 final 3, 20 September 2011. 
diversity of legal systems and traditions - but this fact, ultimately, increases rather than reducing the importance of consistency and coherence in European criminal legislation.

In the Communication, criminal investigations and sanctions are seen as having an impact on citizens' rights. Since these also have a stigmatizing effect, criminal law measures should remain the last resort - ultima ratio. ${ }^{34}$ A test needs to be developed to assess whether this requirement is satisfied. The relevant question is, of course, why a criminal law measure is needed and why other means do not suffice. This is the first part, the general test. As a second step, the proposed measure needs to pass another test: this includes a test concerning necessity and proportionality (actproportionality). ${ }^{35}$

The Communication even includes an explanation of the term 'effective, proportionate and dissuasive'. Effectiveness means, according to this reading, suitability to achieve the desired goal. Proportionality requires that the sanction must be commensurate with the gravity of conduct and its effects and must not exceed what is necessary to achieve the aim. Dissuasiveness means that the sanction constitutes an adequate deterrent for the potential future perpetrators. ${ }^{36}$

To my mind, this approach clearly indicates that criminal law is a carrier of values and that criminal justice communicates those values. Even though the domestic legal systems are the ones that do the job, the contours of European criminal law are becoming visible. The Commission's proposal to place limits on the use of criminal law is a very important sign of maturity in this respect. A clear recognition of the criminal law principle of proportionality is also significant since it differs from the broader notion of proportionality (act-proportionality vs means-end-proportionality). I would interpret all of this as an effort to increase the legitimacy of criminal law. Increased legitimacy, in turn, gives us reasons to contemplate how this change will affect the role we see criminal law fulfilling.

An expert working group was set up to advise the Commission when proposing criminal law legislation. In one of its meetings, the Expert Group discussed the term 'effective, proportionate and dissuasive'. One of the observations of the group was that when assessing the effective, proportionate and dissuasive character of sanctions one should consider not only the legislative level but also the application in practice, including procedural aspects. To ensure that an imposed sanction is actually enforced is key for deterrence and for the credibility of the system. The EU should accordingly work on improving enforcement in and between the Member States. ${ }^{37}$

The Expert Group did not elaborate further on whether the new criminal policy approach of the EU, together with all the developments that have already shaped EU criminal law, called for a change to the formula itself. The formula might have needed reinterpretation, modification or replacement. It is unclear why the Expert Group was cautious in this respect, but it may arise from differences of opinion among the scholars themselves. In their discussion on approximation of sentencing, the Expert Group was divided in its approach. 'Whereas some experts aimed at creating more equality in sentencing between Member States, others focused on the preservation of the coherence of the national legal systems'. ${ }^{38}$

34. ibid 7.

35. ibid 7-8.

36. ibid 9.

37. Key findings, Expert Group on EU Criminal Policy, Meeting 19 June $2012<$ http://ec.europa.eu/transparency/regex pert/index.cfm?do=groupDetail.groupDetail\&groupID=2760> accessed 16 July 2019.

38. Key findings, Expert Group on EU Criminal Policy, Meeting 12 March $2014<$ http://ec.europa.eu/transparency/ regexpert/index.cfm?do=groupDetail.groupDetail\&groupID $=2760>$ accessed 16 July 2019. 
A novel approach to the communication of blame would be needed to interpret the meaning for EU criminal law of the fact that conviction and sentencing in one Member State may be different from one in another Member. Is it a shortcoming? Or is it maybe simply a feature which enables us to learn? Since we all know this fact, we will be able to learn about those differences. For a Pole to learn about sentencing in France may contain some surprises, but the moral message of the sentencing comes through in any case. Once we see that we should look behind the surface level of law and legal practice, we start seeing the dimension of values. Only if we force ourselves to a narrow rational actor model do we face a problem here.

This problem is easily solved once we adopt a positive general prevention approach, or more broadly an approach which allows for a more social and sociological reading of the law. Even if the sentence in France were more lenient (or more harsh, for that matter) than the one a Polish court would impose in a similar case, the French court's judgment could very well contribute to an understanding that certain rules of conduct apply and are effectively criminally sanctioned and can and will be dealt with by the French authorities. This message would be sent to the entire population of EU.

This is where things get really exciting. The new approach would cast new light on the idea of developing a common European legal consciousness, a common mindset. This was an idea that we used to see references to, that there should be a mental equivalent to the legal practices created through criminal law cooperation. In the early days I was of the opinion that this was impossible due to the great variety of approaches among the Member States. As long as the purely technical and instrumental approach prevailed, any deeper meaning had to be sought in a domestic context. We could of course continue to be sceptical about the idea of deeper values even domestically, since our communities are diverse and any supposed consensus on values has to be rather abstract. But if we dare to be engaged with a more substantial, legitimacy-based reading, we might see that the European criminal law possesses such features as well. It opens up to a reading of this kind.

My claim is that it is time to look at EU crime policy also in terms of its ability to draw on legitimacy. This would ease the tensions between the EU criminal law level and the domestic level. EU criminal law is of course only a patchwork, especially if we do not include all of the Member States' legal systems in this concept. But we have enough European characteristics to justify talking of a 'European approach'. Surely, in all European criminal justice systems criminal law enjoys a particular position and can be distinguished from administrative law. It is part of European tradition since the Enlightenment that criminal law exists for the protection of freedoms, while affecting some other fundamental rights, and that its use requires justification. And, as we should note, a symbolic dimension is a general feature of law, not only limited to criminal law.

The European Parliament has issued a Resolution on issues of how to develop criminal law at the EU level. ${ }^{39}$ In this Resolution, the European Parliament criticizes existing EU criminal law for its fragmented nature. It therefore contends that criminal law should 'constitute a coherent legislative system governed by a set of fundamental principles and standards of good governance in full respect of the EU Charter of Fundamental Rights, the European Convention on Human Rights and other international human rights conventions...'.

The EU approach, as conceived by the European Parliament, shows in a rather clear and simple way that the EU has been maturing in the way it sees EU-wide collaboration in terms of criminal law measures. Accordingly, it is possible that a new mindset might emerge. It would distinguish 
itself as a European approach which differentiates itself vis-à-vis other approaches. The European approach would distinguish itself not only in taking criminal procedural guarantees seriously, but also as regards a different understanding of how criminal law operates and how it gets its steering force through being legitimate.

In some earlier documents, it was argued that a shared European sense of justice would be useful and that, for instance, harmonization of criminal sanctions across Europe could promote this. ${ }^{40}$ It seems clear that no strong expressions of a shared sense of justice have emerged. But, in any case, we could say that the creation of an AFSJ itself, with so many shared criminal definitions, could be interpreted as expressing some minimum understanding of a shared sense of justice. This has been underlined by existing practices of collaboration in cross-border criminal cases.

The positive general prevention thought is part of European heritage and it can easily be traced to the classic sociological insights of Émile Durkheim and Max Weber, for instance. One could also refer to the communicative theory of Jürgen Habermas. ${ }^{41}$ We should of course not overinterpret the thickness of any such consciousness. It is only one layer of European criminal thought. We should also be mindful that not even on the domestic level can we talk about any shared legal consciousness in a thicker sense. Our communities are far too diverse for that. Having said that, maybe criminal law is there to fill some gaps. It is able to communicate values in a similar sense to a constitution.

A general prevention emphasis fits into European criminal law since the emphasis has been on approximation of crime definitions for so-called 'Eurocrimes'. The definition of the elements of an offence operates precisely on the level of requirements of actions, and as such regulates the conduct which falls within the definition. This may be one of the reasons why a general deterrence approach has been so natural. People simply need to know what is punishable and what not. General deterrence works on this level as well. But what I wish to present is an alternative account, since the theory of positive general prevention has also implications for the so-called special part, and in particular for the elements that must comprise a 'criminal offence'.

We should also remember that this approach does not exclude the relevance of individual prevention. It makes sense to take into consideration individual prevention aspects when the court decides on punishment in an individual case. It is important that we do not read the effectiveness requirement in a way which would exclude such considerations. This would go against the main structure of most criminal justice systems and jeopardize their rationality. It is important that European criminal law recognizes the features of criminal law as these manifest themselves on the level of domestic law.

We are not the first to point out that an instrumental approach needs to be accompanied by something else, something which would account for the non-instrumental values, expressive values and functions. Ester Herlin-Karnell has discussed this, and has also pointed out the risks that incorporating the non-instrumental values will entail. ${ }^{42}$

40. See European Commission, 'Green Paper on the approximation, mutual recognition and enforcement of criminal sanctions in the European Union’ COM (2004) 334 final, 30 April 2004, 9.

41. Jürgen Habermas, Between Facts and Norms: Contributions to a Discourse Theory of Law and Democracy (MIT Press, Cambridge 1996).

42. Ester Herlin-Karnell, 'Effectiveness and the Constitutional Limits in European Criminal Law' (2014) 5 NJECL 267. See also the critical remarks in Elholm (n 1) 219-26. 
Jenia Iontcheva Turner has made the very interesting observation that the Framework Decision concerning Racism and Xenophobia stands out as an effort of the EU to make a statement as regards these forms of crime, in spite of the fact that these crimes are infrequently cross-border in nature. ${ }^{43}$ It is indeed true that racism and xenophobia hit very deep in the European mindset and the core roots underlying European integration. Racism and xenophobia have a direct link to human rights law, and the underlying values grow from European history. We should remember that hate speech offences are in fact a rare case in which the European Court of Human Rights (and the previous European Commission (EC) of Human Rights) has applied the doctrine of prohibition of abuse of rights (ECHR, art 17). ${ }^{44}$

We should note that criminal law's symbolic function really is in some sense detached from its utilitarian deterrence function. We simply have to make this symbolic statement, and the crucial significance of this move is that we recognize that there are legitimate limitations on the use of freedom of speech: speech denying the human dignity of members of certain vulnerable groups is not protected by the article concerning freedom of speech (ECHR, art 10). The ultimate concern is that letting hate speech run wild might pose concrete risks to core European values, something we do not wish to see happening. It is rather obvious that in this context, we regard as secondary the question of how individual potential perpetrators reason in their reflections on this law and the potential punishment it sets for. The legislature really seeks to communicate basic values by this statement. Good expressivists are consequentialists, too, says Cass R. Sunstein. ${ }^{45}$

Sionaigh Douglas-Scott has taken up the case why the EU is having difficulty building its laws on anything like a concept of justice. ${ }^{46}$ She has doubts as to whether we could use the term 'sense of justice' at the European level. She even doubts that human rights could embody such a sense. As I have stated above, I believe that we could interpret at least some EU law to express a view of justice. Criminal law norms may have this capacity. Expressivity may be found whether or not it was intended by the legislature. ${ }^{47}$ These norms would be measured in terms of justice, assuming that this is the minimum requirement. As has been noted, construction and implementation of policy, law and action 'designed to affect the lives of people' axiomatically means that we cannot escape the demands of justice. ${ }^{48}$

'Justice' is a big word and different meanings can be attached to it. If we follow the line chosen by Amartya Sen, we may mean a certain commitment to the improvement of existing human conditions, a pragmatic approach, instead of a full theory of a perfectly just society. Reducing racism might serve the goal for justice in the very sense of addressing a perceived injustice. ${ }^{49}$

What about the 'sense of justice', understood in empirical terms? Is there any hope of us Europeans ever adopting the views propagated by our criminal law against racism? I cannot begin any longer answer here. In some sense, a clear statement is not anything that would directly arise

43. Jenia Iontcheva Turner, 'The Expressive Dimension of EU Criminal Law' (2012) 60 American Journal of Comparative Law 555 .

44. See, for instance, Glimmerveen and Hagenbeek $v$ the Netherlands (App no 8348/78) Decision of the Commission, 11 October 1979, and Williamson v Germany (App no 64496/17) ECHR 8 January 2019.

45. Cass R Sunstein, 'On the Expressive Function of Law' (1995) 144 University of Pennsylvania Law Review $2021,2045$.

46. Sionaigh Douglas-Scott, 'Human Rights as a Basis for Justice in the European Union' (2017) 8 TLT 59.

47. G Davies, 'Social Legitimacy and Purposive Power: The End, the Means and the Consent of the People' in A Williams, D Kochenov and G de Burca (eds), Europe's Justice Deficit? (Hart Publishing, Oxford 2015) 259, 265.

48. A Williams, The Ethos of Europe: Values, Law and Justice in the EU (CUP, Cambridge 2010) 294.

49. Amartya Sen, The Idea of Justice (Allen Lane, London 2009). 
out of popular European legal consciousness. But this is precisely the reason why it is needed. A statement aims at having an impact on that, in the interest of justice, understood in Senian terms. A statement may guide European citizens and inform them in a way which is different from a rational actor model, narrowly defined.

As stated by Rob Schwitters, a sociological account of compliance acknowledges the combined effect of shifts in the opportunity structure and internalization. A legislated rule, which 'brings behavior more in tune with reflected interests', may have further effects since it may 'produce an important change in behavior'. Initially it may be dependent on coercive force, but soon it comes instead to rely on communicative underpinning. ${ }^{50}$

We should, in any event, add that empirical studies have shown that communities may share views in the name of a sense of justice. This has been dealt with extensively by Paul H. Robinson. Communities, however, develop shared understandings only of the core features of criminal law regulations. A (shared) sense of justice does not give answers as regards the penal values in detail. However, a community may share a sense of justice in the sense of recognizing the relative blameworthiness of different offences. ${ }^{51}$

In fact, this finding may partly explain why the approach of approximation of criminal penalties by setting rigid requirements concerning the penalty scales for specific crimes ('minimum maximum penalty range') has not been very successful as a means of harmonizing the national rules on levels of criminal sanctions. The 'message' of the harmonizing instrument simply means very different things when received by the national legal order. A new approach, focusing instead on the relative comparability of the severity of the offence in different national legal orders, would seem a welcome development. We would accordingly wish to make sure that in the national legal order the punishments enjoy a similar relative position. A category-approach has been proposed. Such an approach would very well fit into the idea that the European criminal law touches on the symbolical levels of criminal and promotes the emergence of a European way of looking at certain crimes. This approach deserves closer scrutiny, but prima facie it would help to avoid some of the obvious flaws of the previous regulatory model. ${ }^{52}$

Such an approach would build more on the values enshrined in the national legal orders than the current model which uses rather blunt instruments to approximate penal sanctions. Especially in the long run, an approach built on relative comparability of categories of offences would enable European law to build more directly on the coherence of the national legal order. Today, instead, approximation presents itself as an intervention securing only harmonization as to a minimum level of seriousness.

The EU may exercise some influence on the relative blameworthiness of Eurocrimes. Thus it may exercise some influence on what activities are made punishable. Through both of the routes outlined above, then, we can observe some avenues to impact and express a shared sense of justice. We cannot be too optimistic about this putative European shared sense of justice: the foundations and sources are still very weak and vulnerable and European citizens most likely do not even recognize that these choices rest on a European foundation, since the authorities continue to apply

50. Schwitters (n 27).

51. Paul H Robinson, Intuitions of Justice and the Utility of Desert (OUP, Oxford 2013).

52. H Satzger, 'The Harmonisation of Criminal Sanctions in the European Union' (2019) 2 European Criminal Law Review 115. 
domestic implementing laws. For the most part, only some lawyers know about the EU origins of certain law amendments.

A few words of caution need to be added. I regard it as a benefit that if we turn to the register of blame and communication, we can free ourselves from the iron cage of general deterrence, which basically calls for harsh treatment where needed. If 5 years of imprisonment does not deter, maybe 10 years would. It provides a general rationale for harsher treatment if criminality is a problem, as it almost always is. By making a communicative turn, we can see that the mere existence of criminality does not challenge our criminal policy since crime cannot be made to disappear. There is a cost of fighting crime, and that is a reason why we need a rational crime policy.

In terms of communicative theory, the legitimacy of criminal sanctions is conditional. We would have to discuss separately, for instance, how to justify the use of imprisonment in the first place. ${ }^{53}$ There are many punishment theories, and it is not possible to discuss all of the options and their combinations here. Suffice it to say that the most important choice is the one we take to broaden our perspective from the general deterrence to other viewpoints and that we understand that the ability of criminal law to function grows together with increased legitimacy. ${ }^{54}$ If criminal law is based on moral communication of blame, it needs itself to satisfy high moral criteria. In the French discussion, the expressive function of criminal law has been linked with crime as a transgression of a taboo. Taboos create order. The values are expressed in taboos which give rise to punishments. ${ }^{55}$

International treaty crimes are part of a system of international policymaking which only becomes criminal law in the domestic criminal law systems. European criminal law has the potential to grow to become something more than that. By maturing, it has the potential to become conscious of its distinctive European approach to crime control and crime prevention. Criminal law would be approached in a balanced manner, not as a repressive tool alone.

Mireille Delmas-Marty introduced the concept of Europe as a laboratory of legal pluralism. ${ }^{56}$ What I am proposing here proceeds in a similar direction. Internal market law was originally dominated by economic efficiency, and European human rights law was a quite separate story, with only limited points of contact between the two. What we see today is the emergence of a European law which still regulates the market but which goes way beyond that. Introducing criminal law cooperation to the heart of the legal integration has changed the heart itself. My proposal to take this heart seriously means that we should recognize the potential that a common European crime policy, even a narrow and thin one, may have. We have thus the opportunity to rethink the rationality of our law.

On the European level, this means a merger of regimes and a kind of a collision of rationalities. On the vertical line, we also see that European policies may become more serious, better-informed and more legitimacy-based rather than simply dominated by the external and effectiveness perspectives. For Delmas-Marty, European human rights law presents the source of ethical authority

53. See the discussion in K Günther, 'Criminal Law, Crime and Punishment as Communication' in AP Simester, A du Bois-Pedain and U Neumann (eds), Liberal Criminal Theory: Essays for Andreas von Hirsch (Hart Publishing, Oxford 2014) 123.

54. See, for instance, several essays, including C Roxin's, in the volume Simester, du Bois-Pedain and Neumann (eds) (n 53).

55. See Mireille Delmas-Marty, Towards a Truly Common Law: Europe as a Laboratory for Legal Pluralism (CUP, Cambridge 2002) 10.

56. ibid. 
which is able to grant legitimacy to legal orders which come into contact with it. I do not disagree. I would, at any rate, say that by also reinterpreting the role of criminal law in the European setting we may be able to determine conditions under which the criminal law itself may be perceived as legitimate, and so mediate the systemic frames conferred by the human rights tradition. Since the body of norms of EU criminal law was established before EU criminal policy principles were reflected upon and adopted, the real life of law may of course look worse than what could be expected. This will make the entire enterprise somewhat more difficult. Even if we would start rather working towards securing a relative comparability of the levels of criminal sanctions, the previous measures have already brought about changes which set the stage.

This may all sound complicated but it does not necessarily have to be. Both European criminal law and human rights law have their origin in Enlightenment thought, which heavily criticized preexisting criminal justice practices due to their lack of legitimacy. Criminal law of the ancien régime was not crafted to serve the interest of safeguarding freedom. The quest for legitimacy was formulated in this critique, and the entire development of criminal law in Europe which has followed can be seen as efforts to formulate criminal law which would enjoy a high legitimacy and be restricted to what is necessary in terms of protecting core freedoms. ${ }^{57}$

The story of the role of criminal law in the EC/EU setting was different, since it was originally not meant to be relevant. Over the years, and especially since the Treaty of Amsterdam, criminal law became a central policy field. The domestic criminal justice systems remain different and not convergent by any reasonable standard. Mutual recognition was set as the cornerstone principle. If convergence takes place, reasons other than EU criminal law cooperation for its own sake stand behind it. But, for each domestic system, there is a single European reference point, or two, if we regard European human rights law as a separate entity. Drawing more on the relative comparability approach, a bridge could be created between national values and European values, and the senses of justice informing the two would draw more on each other.

We could even refer to the rule of law discussions and rule of law commitments as part of a general European frame. Since Europe has introduced a system of mutual recognition of judicial decisions, a judicial area has emerged in which the rights of the European citizens are at stake if, for instance, the independence of the judiciary did not exist in some of the Member States. There is a common European reference point, and a common European standard. Most certainly, if we would look at Europe from the outside, both human rights and commitment to high standards of rule of law would stand out. For an outsider, looking at European criminal law as culturally embedded in its thicker forms would be rather natural.

What I have been suggesting above may come as a surprise to many. It would have been a surprise to me too, previously: back in 2003 I wrote rather cynically about any effort to harmonize criminal law on the European level, especially if we would include harmonization of criminal sanctions. I quote myself ${ }^{58}$ :

Taking into consideration the reasons behind the current diversity in Europe, there is not much hope that one could formulate the guiding criminal policy principles, fill them with common evaluations,

57. See, for instance, M Dubber, The Dual Penal State (OUP, Oxford 2018).

58. K Nuotio, 'Reasons for Maintaining the Diversity' in M Delmas-Marty, G Giudicelli-Delage and É LambertAbdelgawad (eds), L’harmonisations des sanctions pénales en Europe (Société de Législation Comparée, Paris 2003) 465, 470. 
and be able to reform the whole of penal sanctions in order to create a reasonable convergence in the area. The differences are not only random and accidental, they are systemic.

What I suggest is that scholarship too could play a role here. It should discuss the deeper rationales of our criminal law thinking and help introduce some of them to the European debates on where to go with criminal law and criminal policy. It might even be helpful to have this debate on the European level since it would be important for the Member States themselves to be mindful of the European heritage. It is of utmost importance that the European approach in fighting terrorism, to give one example, follows the European models and principles which are emerging.

\section{Conclusion}

I propose that we look back at the development of European criminal law and see that it has matured in several ways. European law today recognizes better than it did previously the distinct character of criminal law, a recognition which has come after many years of intense debates of whether criminal law deserves to be treated differently from other fields or not. That recognition, together with other legal developments - especially as concerns the role human rights and fundamental rights on the European level, enables us to take a fresh look at the actual and potential legitimacy of European criminal law. The increased involvement of the European Parliament also deserves to be mentioned. All this calls for taking a fresh look also at the way we see European criminal law operating. In my view, we need to challenge the dominance of narrow effectiveness thinking and the view that general deterrence is the leading understanding of the mechanisms of how criminal law works in the society.

The general deterrence model has obvious advantages since it is a simple form which is easily understandable and which benefits from being based on a model of rational choice and rational action. Economics brings with it a flavour of precision and empirical grounding. The dominance of general deterrence has, however, the disadvantage that it leads to an overtly instrumental approach to criminal law which in turn leads to a failure to recognize the deeper sense in which criminal law is able to communicate values and expectations in a society. This failure has a high price since it leads to the failure to see the potential of increasing effectiveness through legitimacy. Seen through the lens of positive general prevention, European criminal law may have achieved more than what one would assume looking at it only through the lens of law and economics rationality. A fresh look would also enable us to theorize better as too what justice means for our law. The symbolic effects of criminal law, which call for sociological understandings, lead the way towards questions of justice, including those regarding the European mindset, a European sense of justice. The academic proposal to introduce a new model for approximating criminal sanctions is a welcome initiative and it would take us in the right direction.

Having said all that, we should bear in mind that the potential of European criminal law is still rather limited and we should not expect the maturity that I have been speaking about to do away with the structural limitations which still characterize this fragmented field which we call European criminal law. It will remain fragmented and something far less than the criminal law we know it in the national context. In any case, reading criminal law through the lens of criminal law theory, and also through social theory which has at this point informed our theories of crime and punishment for a long time, enables us to recognize the links criminal law has to core values of a society. It also enables us to interpret Europe loosely as a legal community, a criminal law 
community, which shares certain understandings simply since it shares some views on crime and has taken legislative measures to implement those views.

I believe that the reinterpretation that I propose would also serve the purpose of defining European criminal law as something fundamentally European. A law and economics type of instrumental view on criminal law is, in fact, not a very European approach. It would be of particular value to build the European approach on European values, on the European tradition which includes Enlightenment thought and the critique of criminal law as part of it. The sociological approaches to compliance are part of a European heritage. An interpretation which accounts for this tradition would make visible the legitimacy potential of criminal law when properly conceived. It takes seriously the legitimacy requirement and responds to it. It serves European citizens by being what European citizens expect it to be: a European response to problems of criminality. Thus it also speaks the same language as human rights law - equally a very European matter - and the fundamental rights law of the EU. This reinterpretation is a tribute to European tradition, but it should of course not only be a tribute, but it should serve the creation of even more elaborate and rational criminal policy and criminal law for Europe.

\section{Declaration of conflicting interests}

The author(s) declared no potential conflicts of interest with respect to the research, authorship and/or publication of this article.

\section{Funding}

The author(s) received no financial support for the research, authorship and/or publication of this article.

\section{ORCID iD}

Kimmo Nuotio (D) https://orcid.org/0000-0003-4889-1634 